\title{
Leather cutting waste minimization Techniques in Ethiopian footwear industry: case study ELICO -Universal Leather Products Industry
}

Biniyam Bekele Solomon ( $\square$ biniko139@gmail.com)

Bahir Dar University

Research Article

Keywords: footwear industry, leather products, leather cutting, waste minimization, higher productivity

Posted Date: March 11th, 2021

DOI: https://doi.org/10.21203/rs.3.rs-274284/v1

License: (1) This work is licensed under a Creative Commons Attribution 4.0 International License. Read Full License 


\section{Abstract}

This research paper mainly focused on the leather-cutting issues and waste minimization in footwear industry in Ethiopia. The footwear industry is developing every year. The quality is an important parameter for middle scale footwear sectors and lot of inline problems focused in this research process. The objectives of this study were to analyze leather waste scrapes in Ethiopia footwear industry, identifying and implementing advanced leather cutting techniques. The paper selected for an exploratory study, including in-depth raw data collocation for two months in the company by using a spread sheet, automated machine vision for Leather Defect Inspection machine and checklist and one expert group discussion with employees representing cutting departments and the research conduct the top management to analyze the current system those implanted in the company to reduce leather cutting waste. The data were complemented by documentary analysis, to compare and contrast after implementation of advanced cutting system in the company. The paper provides how much waste of leather scrap is producing cutting operations, and by what method they eliminating waste and controlling the waste in current time. The paper includes implications for the implementation-advanced techniques/method in cutting a section to reduce leather waste scrape through by giving training for operators. This paper fulfils an identified need to study how much Leather cutting waste generated and by what method and Techniques minimizing the waste in Ethiopian footwear industry: case study ELICO -Universal Leather Products. The analytical findings show that the application of Jigsaw Puzzle cutting method, tools, and techniques has been expanded beyond traditional cutting concepts and has improved Leather Shortage (Extra Norms) eliminated and Leather Saving Norms was increased and leather waste scrapes was reducing from $212.89 \mathrm{~m}^{2}$ to $151.09 \mathrm{~m}^{2}$ of leather.

\section{Introduction}

Leather from different parts of animal [1] varies in its characteristics, and this must be taken into account when [2] using leather as products. The hide [3] thickness varies all over the animal and to get it to the right thickness [4] it is usually split on special cutting machines or buffed an even thickness. The main parts of the hides and skins vary property stated that K.T Sarkar [5] (Defect of hide and skins in the Manufacturing of leather) such as the shoulder, Belly, Axillae. Different parts of the hide have different properties in terms of strength, flexibility and durability. Footwear can be defined as a garment that is worn on the feet; there main purposes are protecting one foot. Footwear has become an important component of fashion associates, although their basic purposes remain that of protection, adornment or defining style statements has become their additional and a significant function is the statement says that A.B. Habib [6]. Many types of footwear's shoes, boots, sandals, and slippers shoes are further divided into many categories such as athletic shoes, such as sneakers, glosses, high heel, and stiletto heels. Kitten heels, lace shoes, high-tops, loafers, platform shoes, school shoes and many others. Shoe making are considered traditional handcraft profession however now it has been largely taken over by industrial manufacture of footwear. Today much material is used for making shoes, such as leather, fabrics, plastic, rubber, wood, jute fabrics, and metal etc. More than 200 operators are required for making a pair of shoes, However with the development of modern machines, a pair of shoes can be made in a little time as each step in its manufacturing is generally performed by a separate footwear making machines was clarified SATRA 2007 Publication [7].

Leather cutting is critical operation in footwear industry, in this department, the top part of the shoes or upper is made, clicking operative is given the skin of leather, mostly cow leather. Buff, goat leather used for upper making is stated that Eraivan Elamvazhuthi [8] (IJMME -IJENS 2009 Malaysia Publication) . This operation need a high level of skill as the expensive leather must be wasted at the minimum level possible. Leather may also have various defects on surfaces such as barbed wire scratches that need to be avoided, So that they are not used for upper making now days footwear industry try meet lot of challenges, such as footwear production quality, cost minimization, waste minimization, production efficiency, higher productivity, unskilled manpower, production targets, financial factors [ 9] .This research work particularly focused on the leather-cutting issues and waste minimization in ELICO -Universal Leather Products Addis Ababa Ethiopia. In this project, particularly leather cutting, area layout design , cutting operation, time study management, standard operating procedure in leather cutting, leather cutting and nesting methods, leather sorting, leather quality-grading techniques, cutting machine quality maintained methods, materialsaving techniques, cutting allocation sheet methods, cutting Die allocation methods, damage die cabinet systems, Die checking marble stone, leather cutting waste minimization techniques, daily cutting stroke reports systems, was analysed and adopted in this research work.

\section{Materials And Methods}

\subsection{Materials}

\section{Selection of cutting leather}

In the footwear production commonly used for Goat skin, cow leather, buff leather, pig leather sheep skin. Finishing is a critical factor in footwear production leather, finishing having lot of varieties such as full grain leather, correct grain leather. Suede leather, patent leather, PU coated leather, Semi aniline finish leather, pigmented leather finish etc. Grain feel off, defected leather surface, poor thickness, improper finishing shade, more looseness, color feel off, poor strength, testing failure, more chemical contents, is common leather problems in footwear industry [10]. The study use commercially-available leather those tanned by Chrome and vegetable tanned leather with different thicknesses and color was used to prepare leather upper shoe seam and the physical properties of leather as shown in Table 1 below.

Table 1 Physical properties of leather 


\begin{tabular}{|c|c|c|c|c|c|c|}
\hline Leather type & Sample & $\begin{array}{l}\text { Leather } \\
\text { thickness } \\
(\mathrm{mm})\end{array}$ & $\begin{array}{l}\text { Leather } \\
\text { density } \\
\text { [g/m2] }\end{array}$ & $\begin{array}{l}\text { Leather tensile strength } \\
{[\mathrm{Nmm} 2]}\end{array}$ & $\begin{array}{l}\text { Leather tearing strength } \\
{[\mathrm{N}]}\end{array}$ & $\begin{array}{l}\text { Flexing endurance } \\
\text { (cycle) }\end{array}$ \\
\hline \multirow{4}{*}{$\begin{array}{l}\text { Box calf } \\
\text { leather }\end{array}$} & 1 & 1.2 & 435 & $25.98 \pm 10.29$ & $41.16 \pm 9.80$ & No damage@100000 \\
\hline & 2 & 1.5 & 498.5 & $26.78 \pm 11.39$ & $46.96 \pm 12.90$ & No damage @100000 \\
\hline & 3 & 1.7 & 534.1 & $25.88 \pm 10.19$ & $49.76 \pm 13.50$ & No damage@100000 \\
\hline & 4 & 2.0 & 597.5 & $25.98 \pm 11.29$ & $45.06 \pm 11.90$ & No damage@100000 \\
\hline \multirow[t]{4}{*}{ Pig leather } & 1 & 1.2 & 341.6 & $27.18 \pm 12.59$ & $49.89 \pm 14.78$ & No damage@100000 \\
\hline & 2 & 1.5 & 390 & $29.38 \pm 11.69$ & $54.76 \pm 15.67$ & No damage @100000 \\
\hline & 3 & 1.7 & 410.78 & $26.78 \pm 10.19$ & $53.96 \pm 14.59$ & No damage@100000 \\
\hline & 4 & 2.0 & 452.5 & $25.67 \pm 11.89$ & $43.06 \pm 10.50$ & No damage@100000 \\
\hline \multirow[t]{4}{*}{ Sued leather } & 1 & 1.2 & 324 & $26.98 \pm 12.59$ & $53.76 \pm 14.50$ & No damage@100000 \\
\hline & 2 & 1.5 & 378 & $25.78 \pm 13.19$ & $55.06 \pm 13.56$ & No damage@100000 \\
\hline & 3 & 1.7 & 411.9 & $29.98 \pm 14.79$ & $54.76 \pm 12.70$ & No damage@100000 \\
\hline & 4 & 2.0 & 478.67 & $26.78 \pm 12.09$ & $43.08 \pm 10.50$ & No damage @100000 \\
\hline \multirow{4}{*}{$\begin{array}{l}\text { Nubuck } \\
\text { leather }\end{array}$} & 1 & 1.2 & 324 & $27.98 \pm 11.19$ & $55.06 \pm 13.56$ & No damage @100000 \\
\hline & 2 & 1.5 & 378 & $25.08 \pm 11.09$ & $43.08 \pm 10.50$ & No damage @100000 \\
\hline & 3 & 1.7 & 411.9 & $26.08 \pm 12.19$ & $53.96 \pm 14.59$ & No damage @100000 \\
\hline & 4 & 2.0 & 478.67 & $27.08 \pm 13.99$ & $53.96 \pm 14.59$ & No damage@100000 \\
\hline \multirow[t]{4}{*}{ Pull-up leather } & 1 & 1.2 & 567.5 & $25.18 \pm 11.09$ & $44.76 \pm 10.90$ & No damage @100000 \\
\hline & 2 & 1.5 & 610.5 & $27.08 \pm 13.89$ & $47.76 \pm 12.50$ & No damage@100000 \\
\hline & 3 & 1.7 & 679.89 & $25.48 \pm 11.89$ & $48.45 \pm 12.99$ & No damage@100000 \\
\hline & 4 & 2.0 & 710.67 & $26.28 \pm 11.09$ & $43.76 \pm 11.50$ & No damage @100000 \\
\hline \multirow[t]{4}{*}{ Patent leather } & 1 & 1.2 & 410.45 & $25.98 \pm 10.19$ & $55.06 \pm 13.56$ & No damage@100000 \\
\hline & 2 & 1.5 & 478.8 & $26.78 \pm 11.19$ & $54.76 \pm 12.70$ & No damage@100000 \\
\hline & 3 & 1.7 & 514 & $25.98 \pm 10.09$ & $43.08 \pm 10.50$ & No damage @100000 \\
\hline & 4 & 2.0 & 598 & $27.68 \pm 13.19$ & $55.06 \pm 13.56$ & No damage @100000 \\
\hline
\end{tabular}

\subsection{Methods}

\section{The Advanced leather-grading method}

Leather selection, assortment, quality grading is a critical factor in footwear industry. Right now SATRA five point-grading systems are used for many countries, grading is the key point for footwear industry. Grain defects, wein marks, color feel off, poor strength, flaying cuts, machinery defects are common problems in finished leather grading Leather inspection area record is must such as, leather material introduction, color swatch, sample shoe, inspection tools like gauge meter measuring machines, Hardness calibrator, Multi light box is very important for leather grading process. In this research, leather cutting coefficiency and cutting the average standard is properly handled by leather-cutting section in ELICO -Universal Leather Products. In case-poor-grade leather is selected to footwear production cutting average and component quality may be affected and footwear final product value is totally failure.This research refers to the SATRA five points grading rules and well-trained assisting skills. SATRA Leather grading having AQL level 1 light inspection (Accepted quality level), AQL 2.5 Level -Normal inspection. In addition, AQL Level 4 (Minor leather inspection) [10].This type of inspection was used in the leather-grading process to avoid poor leather up normal issues.

\section{Leather manual nesting methods}

Before cutting nesting technical skill is critical for upper leather-cutting operator, finished leather having so much quality variation such as loose fibre leathers, Brand marks, operation scar, open flaws, closed Flaws, wire marks, scratches. Growth marks, fat wrinkles, veins, flayed cuts, discolored finishing area, boarder area, insect or parasitic damage, etc. The above defects are avoided by proper nesting operation, after cutting die interlocking properly, in cutting process cuttabilty co efficiency, norms saving, waste minimization also critical without nesting knowledge cutting leather cost, quality, working time also strongly affected this statement stated that EDRI report 2013 in Ethiopia [11]. In footwear leather component quality is the main key for finished products, nesting and dies interlocking skill is must, all upper to be properly trained [12] by industry it will improve the cuttabilty and leather cutting issues minimized short period [13]. Wrong direction cutting in leather and other materials is also nowadays big problems in all footwear industry. Based on the above technical statement in ELICO -Universal Leather Products advanced manual leather-nesting training was given to at all level of upper cutting operators. 
Leather is natural material with several physical [14] characters such as the shoulder, Belly, Axillae. In cutting process, each and cut component cutting stretch direction is critical, shoulder area is thick and strong, but tends crease easily as this part of the hide or skin affected by moments of head. Area fiber in this part of the hide is tightly packed and hence to the strongest part of the hide, prime footwear components mostly cutting in this part, Belly area is silent and thin and has a much looser fibre structure than the back, and often stretches under stress. This area not suitable for cut components in the case unskilled cutting operator will cut prime components in this area total footwear quality meets loses problems is stated that Professor Vi-Nguyen China [15]. Axillac these are like human armpits they move a lot the fiber [16] structure than the belly area, this part is more lost and not suitable for any footwear components cutting, mostly this part avoided by cutting process. Footwear industry meet lot critical quality issues in cutting section, this is the base of the bulk production so special attention and quality implementation techniques, cutting section design layout. Machine maintenance, lighting effects measurements are critical parameters. Based on the above statements in ELICO -Universal Leather Products we implemented leather-grading data, form data (Die intimation details), SOP detail, leather color swatches, sample shoes are to be arranged in all leather-cutting sections. Most of the industries they are not given special focus to cutting section this is the main reason for the final product quality issues. Leather components cutting stretch direction knowledge is important for upper cutters, so leather-cutting operators properly trained by quality standard methods by this research process. In this way of methods leather-cutting norms and material saving, waste minimization is controlled and company leather investing cost is reduced.

\section{Cutting implementation}

Footwear industry leather cutting section one of the biggest issues such as lack of cutting, loose leather components cutting, uneven grain components cut, components colour-matching issues [17]. Cutter die interlocking skill is poor this type of problem is not controlled easily. Each and every component interlocking width Minimum 4mm must, this allowance is not properly handled that above types of issues coming in section area. In case some times cutting formula suddenly changed according to customer requirement, Leather is cost and investment also affected by poor trained leather cutters. Standard cutting operating chart is arranged in all machines, proper trained quality supervision, cutting die check list data, cutting components allocation sheet systems is to be arranged in all cutting machines. Cutting operator has well pair grain-matching knowledge, this skill to avoid the uneven grain upper quality problems. Based on the above Ethiopian Footwear industry competitiveness advanced cutting implementation systems such as SOP, hourly QC report, stroke report, leather norms consumption record systems, workers safety prevention and Jigsaw Puzzle cutting method was implemented in the cutting section and this research suggested that cutter well training programme is must in all middle scale Ethiopian footwear industry.

\section{Cutting board and machines maintenance method}

A cutting board with two types of material cutting board (white) and leather cutting board (green or Red Colour) .This boarding regularly maintains color management system every two hours, Normally yellow, blue, green, Red, colour used for cutting board colour managements systems .The board four edges are coloring and 180-Degree angle ,360 Degree angles changed so board particular area only undamaged, uniform cutting board thickness maintained achieved, cutting components edges quality also improved by this techniques. PU cutting board $16 \mathrm{~mm}$ thickness minimum, below 16 mm thickness board not suitable for leather-cutting operation. Cutting section having a proper light effect and ventilation, waste piece collection bag or tank is allotted to all cutting machines, machines maintained record, break down slip systems also improve the quality and cutting production efficiency [18]. Cutting machines die storage table EVA foam is fixed properly it will avoid the die damage and operator injuries.

\section{Cutting a stroke record method}

Footwear industry day by day fast developments in African countries such as Ethiopia, Kenya, South Africa, Morocco, Egypt. India and China have more developed footwear industries, they have many machines and advanced technologies ,but developing countries is be need some quality implementation techniques in each operation, this article analyses in all quality problems in leather cutting section and it will introduce some process techniques to avoid the above types of quality issues. Cutting area time study management, upper cutter training, safety management, cutting production efficiency, daily cutting record notes systems, operator-cutting stroke report is to be maintained in all middle footwear sectors, company easily will developed . Unskilled cutting operator cutting stroke is poor, normally skilled upper cutting operator international SATRA standards per day 2500 Stroke (8 Hours) capacity and lining and other material cutting operator 3200 stroke $(8 \mathrm{~h})$.

\section{Results And Discussion}

In this section, data collected from ELICO -Universal Leather Products industry from cutting a section by recording one-month data of waste generated using the traditional cutting method, and also after implantation Jigsaw Puzzle cutting method one month data was recorded to compare and contrast the improvement of the cutting department's workers.

\subsection{Data before implantation of Jigsaw Puzzle cutting method}

In a Table 2 is shown that the study determined that $585.36 \mathrm{~m}^{2}$ of leather is cut for specific products based on daily production target of the company, 212.91 $\mathrm{m}^{2}$ leather waste scrap is generated from $585.36 \mathrm{~m}^{2}$ of leather, and the cutting department performs $30.36 \%$ average cutting efficiency.

Table 2.Leather cutting waste recorded 


\begin{tabular}{|lllllllllll|}
\hline Test & \multicolumn{7}{l}{ Total cutting area } & \multicolumn{5}{l|}{ Generated leather waste scrap } & \multicolumn{4}{l|}{ Cutting efficiency } \\
\cline { 2 - 10 } & $\left(\mathrm{m}^{2}\right)$ & Stdev $\left(\mathrm{m}^{2}\right)$ & $\mathrm{CV}(\%)$ & $\left(\mathrm{m}^{2}\right)$ & $\mathrm{Stdev}\left(\mathrm{m}^{2}\right)$ & $\mathrm{CV}(\%)$ & $\left(\mathrm{m}^{2}\right)$ & Stdev $\left(\mathrm{m}^{2}\right)$ & $\mathrm{CV}(\%)$ \\
\hline 1 & 110.38 & 4.83 & 4.38 & 36.49 & 9.59 & 26.30 & 355.167 & 89.34 & 25.15 \\
\hline 2 & 129.42 & 16.09 & 12.43 & 41.22 & 15.47 & 37.53 & 337.277 & 107.10 & 31.75 \\
\hline 3 & 116.99 & 19.29 & 16.49 & 46.60 & 11.36 & 24.37 & 439.731 & 142.73 & 32.46 \\
\hline 4 & 112.54 & 12.26 & 10.89 & 41.22 & 14.91 & 36.18 & 366.297 & 117.12 & 28.79 \\
\hline 5 & 116.28 & 18.74 & 16.12 & 47.36 & 15.05 & 31.77 & 440.527 & 148.22 & 33.66 \\
\hline
\end{tabular}

Figure 1.The above shown that the study determined that the total cutting leather area is different from one operation to other operations, the total generated leather cutting waste also pass through increasing and decreasing their size and the total cutting efficiency also different from one operation to other operation.

Table 3 Total leather-cutting Consumption, Leather Shortage and saving details (Average Value) before implementation jigsaw puzzle cutting method

\begin{tabular}{|c|c|c|c|c|c|}
\hline \multicolumn{6}{|c|}{ Monthly Leather Cutting Total Consumption and Leather Shortage, saving details (Average Value) } \\
\hline \multicolumn{6}{|c|}{ Before implementation jigsaw puzzle cutting method } \\
\hline $\begin{array}{l}\text { No } \\
\text { week }\end{array}$ & $\begin{array}{l}\text { Leather Cutting Norms for one } \\
\text { pair }\left(\mathrm{m}^{2}\right)\end{array}$ & $\begin{array}{l}\text { Total leather cuttability } \\
\text { per day }\end{array}$ & $\begin{array}{l}\text { Total no. of } \\
\text { pairs }\end{array}$ & $\begin{array}{l}\text { Leather Cutting Consumption } \\
\left(\mathrm{m}^{2}\right)\end{array}$ & $\begin{array}{l}\text { Leather Shortage (Extra } \\
\text { Norms) }\end{array}$ \\
\hline 1 & 34.98 & $6 * 523$ & 3138 & 109779.3 & $3.25 \%$ \\
\hline 2 & 36.16 & $6 * 467$ & 2802 & 101342.5 & $2.8 \%$ \\
\hline 3 & 27.55 & $6 * 654$ & 3924 & 108131.8 & 3.74 \\
\hline 4 & 30.89 & $6 * 453$ & 2718 & 83968.35 & $3.23 \%$ \\
\hline 5 & 33.90 & $6 * 568$ & 3408 & 115556.5 & $4.15 \%$ \\
\hline
\end{tabular}

Note: ${ }^{*}$ Rose=Leather Cutting Norms for one pair shoe depend on their design, Green=Total no. of pairs, Blue= Leather Cutting Consumption, Red=Leather Shortage (Extra Norms) Units: Measured in $\mathrm{m}^{2}$ '

Figure 2 the study determined that leather-cutting norms for one pair shoe are different from one design to another design, leather-cutting consumption of the company is different from one to other week and because of the method implement in the cutting department they faced by leather shortage(extra norms).

This research process mainly focused on the footwear company leather cutting section quality issues and refers to some quality standards methods and advanced implementation techniques to the ELICO-Universal Leather Products leather-cutting sections. Now days Vietnam, Bangladesh, India, China, having more footwear industry, right now some Europe customers give the special focus to African countries, here having lot of cattle population and price wise also cheap than Asian countries, Ethiopia having more cattle population in African countries, footwear industry also day by days very fast movements than other African countries. The footwear industry productivity and quality critical for exports and this factor is clarified by Mr.Vasiliki Tsaknaki 2014 Publication (13) (Material for Grafting and interactive and physical artifacts).Customer always such as standard quality, price, and fast delivery, this is the main factor. So each middle sector having sufficient quality requirement and minimum knowledge higher production efficiency and fast delivery moments is must.

The result of Automated Machine Vision for Leather Defect Inspection machine before cutting the process shown in Table 4, 5,6,7,8 below.

Table 4.Quality inspection one in cutting section

\begin{tabular}{|c|c|c|c|c|c|c|c|c|c|c|c|}
\hline \multicolumn{6}{|c|}{ Quality checking 1} & \multicolumn{6}{|c|}{ Quality checking 2} \\
\hline QC1 & $Q C 2$ & QC3 & QC4 & QC5 & QC6 & QC1 & $Q C 2$ & QC3 & QC4 & QC5 & QC6 \\
\hline \multicolumn{6}{|c|}{ Source of leather defect } & \multicolumn{6}{|c|}{ Source of leather defect } \\
\hline $\begin{array}{l}\text { Tannin } \\
\text { stains }\end{array}$ & Looseness & $\begin{array}{l}\text { liming } \\
\text { stains }\end{array}$ & $\begin{array}{l}\text { Fatty } \\
\text { spun }\end{array}$ & $\begin{array}{l}\text { Tannin } \\
\text { stains }\end{array}$ & holes & scratch & $\begin{array}{l}\text { Vein } \\
\text { marks }\end{array}$ & cracks & $\begin{array}{l}\text { Grain } \\
\text { crack }\end{array}$ & holes & holes \\
\hline \multicolumn{6}{|c|}{ Defect area covered $\left(\mathrm{m}^{2}\right)$} & \multicolumn{6}{|c|}{ Defect area covered $\left(\mathrm{m}^{2}\right)$} \\
\hline 12.92 & 26.91 & 10.76 & 5.38 & 10.76 & 5.38 & 10.76 & 16.15 & 16.15 & 21.53 & 5.38 & 10.76 \\
\hline \multicolumn{6}{|c|}{ Inspected area $\left(\mathrm{m}^{2}\right)$} & \multicolumn{6}{|c|}{ Inspected area $\left(\mathrm{m}^{2}\right)$} \\
\hline 113.02 & 120.55 & 150.69 & 129.17 & 139.93 & 118.40 & 107.64 & 91.92 & 104.95 & 107.64 & 129.17 & 118.40 \\
\hline
\end{tabular}

(a)

(b) 
Note: *Red=Leather quality checking before done cutting operation, Blue=Source of leather defect, Green= Defect area covered, Rose=Inspected area Units: Measured in " $\mathrm{m}$ "'

Table 5.Quality inspection two in cutting section

\begin{tabular}{|c|c|c|c|c|c|c|c|c|c|c|c|}
\hline \multicolumn{6}{|c|}{ Quality checking 2} & \multicolumn{6}{|c|}{ Quality checking 4} \\
\hline QC1 & $Q C 2$ & QC3 & QC4 & QC5 & QC6 & $Q C 1$ & $Q C 2$ & QC3 & QC4 & QC5 & QC6 \\
\hline \multicolumn{6}{|c|}{ Source of leather defect } & \multicolumn{6}{|c|}{ Source of leather defect } \\
\hline $\begin{array}{l}\text { Poor } \\
\text { pattern }\end{array}$ & $\begin{array}{l}\text { Grain } \\
\text { crack }\end{array}$ & $\begin{array}{l}\text { Poor } \\
\text { pattern }\end{array}$ & scar & Machine defect & holes & $\begin{array}{l}\text { liming } \\
\text { stains }\end{array}$ & $\begin{array}{l}\text { Fatty } \\
\text { spun }\end{array}$ & holes & $\begin{array}{l}\text { Vein } \\
\text { marks }\end{array}$ & $\begin{array}{l}\text { Vein } \\
\text { marks }\end{array}$ & scratch \\
\hline \multicolumn{6}{|c|}{ Defect area covered $\left(\mathrm{m}^{2}\right)$} & \multicolumn{6}{|c|}{ Defect area covered $\left(\mathrm{m}^{2}\right)$} \\
\hline 37.67 & 16.15 & 22.60 & 5.38 & 12.92 & 5.38 & 12.92 & 16.15 & 16.15 & 5.38 & 10.76 & 5.38 \\
\hline \multicolumn{6}{|c|}{ Inspected area $\left(\mathrm{m}^{2}\right)$} & \multicolumn{6}{|c|}{ Inspected area $\left(\mathrm{m}^{2}\right)$} \\
\hline 94.19 & 134.55 & 118.41 & 107.64 & 117.87 & 117.87 & 123.79 & 109.80 & 129.17 & 118.41 & 145.32 & 123.79 \\
\hline
\end{tabular}

(a)

(b)

Note: ${ }^{\star}$ Red=Leather quality checking before done cutting operation, Blue=Source of leather defect, Green= Defect area covered, Rose=Inspected area Units: Measured in $\mathrm{m}^{2}$ '

Table 6.Quality inspection three in cutting section

\begin{tabular}{|c|c|c|c|c|c|c|c|c|c|c|c|}
\hline \multicolumn{6}{|c|}{ Quality checking 5} & \multicolumn{6}{|c|}{ Quality checking 6} \\
\hline$Q C 1$ & $Q C 2$ & $Q C 3$ & QC4 & $Q C 5$ & QC6 & $Q C 1$ & $Q C 2$ & QC3 & QC4 & QC5 & QC6 \\
\hline \multicolumn{6}{|c|}{ Source of leather defect } & \multicolumn{6}{|c|}{ Source of leather defect } \\
\hline $\begin{array}{l}\text { Grain } \\
\text { crack }\end{array}$ & $\begin{array}{l}\text { Grain } \\
\text { crack }\end{array}$ & $\begin{array}{l}\text { Poor } \\
\text { pattern }\end{array}$ & $\begin{array}{l}\text { Grain } \\
\text { crack }\end{array}$ & $\begin{array}{l}\text { Poor } \\
\text { pattern }\end{array}$ & pox & $\begin{array}{l}\text { Vein } \\
\text { marks }\end{array}$ & $\begin{array}{l}\text { Vein } \\
\text { marks }\end{array}$ & scar & holes & $\begin{array}{l}\text { Vein } \\
\text { marks }\end{array}$ & scar \\
\hline \multicolumn{6}{|c|}{ Defect area covered $\left(\mathrm{m}^{2}\right)$} & \multicolumn{6}{|c|}{ Defect area covered $\left(\mathrm{m}^{2}\right)$} \\
\hline 5.38 & 16.15 & 16.15 & 10.76 & 16.15 & 26.91 & 27.99 & 21.53 & 21.53 & 17.22 & 12.92 & 5.38 \\
\hline \multicolumn{6}{|c|}{ Inspected area $\left(\mathrm{m}^{2}\right)$} & \multicolumn{6}{|c|}{ Inspected area $\left(\mathrm{m}^{2}\right)$} \\
\hline 115.72 & 102.69 & 104.95 & 118.41 & 129.17 & 118.41 & 104.95 & 102.26 & 126.48 & 113.02 & 117.87 & 117.87 \\
\hline
\end{tabular}

(a)

(b)

Note: ${ }^{\star}$ Red=Leather quality checking before done cutting operation, Blue=Source of leather defect, Green= Defect area covered, Rose=Inspected area Units: Measured in $\mathrm{m}^{2}$,

Table 7.Quality inspection four in cutting section

\begin{tabular}{|c|c|c|c|c|c|c|c|c|c|c|c|}
\hline \multicolumn{6}{|c|}{ Quality checking 7} & \multicolumn{6}{|c|}{ Quality checking 8} \\
\hline$Q C 1$ & QC2 & QC3 & QC4 & QC5 & QC6 & QC1 & $Q C 2$ & QC3 & QC4 & QC5 & QC6 \\
\hline \multicolumn{6}{|c|}{ Source of leather defect } & \multicolumn{6}{|c|}{ Source of leather defect } \\
\hline Fatty spun & Fatty spun & Fatty spun & Vein marks & Vein marks & Grain crack & pox & scar & Grain crack & scratch & scratch & scratch \\
\hline \multicolumn{6}{|c|}{ Defect area covered $\left(\mathrm{m}^{2}\right)$} & \multicolumn{6}{|c|}{ Defect area covered $\left(\mathrm{m}^{2}\right)$} \\
\hline 13.99 & 26.91 & 10.76 & 16.15 & 16.15 & 16.15 & 16.15 & 26.91 & 5.38 & 16.15 & 26.91 & 16.15 \\
\hline \multicolumn{6}{|c|}{ Inspected area $\left(\mathrm{m}^{2}\right)$} & \multicolumn{6}{|c|}{ Inspected area $\left(\mathrm{m}^{2}\right)$} \\
\hline 123.79 & 109.80 & 129.17 & 118.41 & 145.32 & 123.79 & 115.72 & 102.69 & 104.95 & 118.41 & 129.17 & 118.41 \\
\hline
\end{tabular}

(a)

(b)

Note: *Red=Leather quality checking before done cutting operation, Blue=Source of leather defect, Green= Defect area covered, Rose=Inspected area Units: Measured in $\mathrm{m}^{2}$, 


\begin{tabular}{|c|c|c|c|c|c|}
\hline \multicolumn{6}{|c|}{ Quality checking 9} \\
\hline$Q C 1$ & $Q C 2$ & QC3 & QC4 & QC5 & QC6 \\
\hline \multicolumn{6}{|c|}{ Source of leather defect } \\
\hline pox & scar & scratch & scar & Grain crack & scar \\
\hline \multicolumn{6}{|c|}{ Defect area covered $\left(\mathrm{m}^{2}\right)$} \\
\hline 17.22 & 10.76 & 21.53 & 18.30 & 18.30 & 16.15 \\
\hline \multicolumn{6}{|c|}{ Inspected area $\left(\mathrm{m}^{2}\right)$} \\
\hline 94.19 & 102.26 & 115.72 & 113.02 & 117.87 & 117.87 \\
\hline
\end{tabular}

Note: *Red=Leather quality checking before done cutting operation, Blue=Source of leather defect, Green= Defect area covered, Rose=Inspected area Units: Measured in $\mathrm{m}^{2}$ '

Figure 3 shows that the study determined that the total defect area covered in quality inspection one $152.85 \mathrm{~m}^{2}$, quality inspection two $166.85 \mathrm{~m}^{2}$ quality inspections three was $198.06 \mathrm{~m}^{2}$, quality inspection four was $207.75 \mathrm{~m}^{2}$ and quality inspection five was $102.26 \mathrm{~m}^{2}$, this shows us the source of the leather defect is impact on the area covered in the leather, total inspected area of leather in quality inspection one $1431.54 \mathrm{~m}^{2}$, quality inspection two $1440.80 \mathrm{~m}^{2}$ quality inspection three was $1371.08 \mathrm{~m}^{2}$ quality inspection four was $1439.61 \mathrm{~m}^{2}$ and quality inspection five was $660.93 \mathrm{~m}^{2}$,this shown us total inspected area was different from one quality checking process to the next one.

Based on this Jigsaw Puzzle cutting method implementation system was implemented in ELICO -Universal Leather Products in Ethiopia, Normal leather cutting efficiency and leather consumption is compared with after the implementation process. The leather cutting section hourly cutting productivity and leather cutting consumption and leather excess norms or saving data were collected every week, this work efficiency and cutting section cut component quality and cut components on time delivery moments also compared with previous productivity. Based on this valuable estimation, workers safety prevention training and workers motivation factor also improved by this advanced cutting technique. From the above methods the ELICO -Universal Leather Products company monthly cutting leather norms gradually achieved and cutting efficiency also improved than previous cutting process. Every week total cutting pairs norms and leather-cutting shortage and saving record system also implemented for reducing leather norms stages. Cutting section excess cutting and leather scrap disposal quantity level was reduced by this advanced waste reduction method.

\subsection{Data after implantation of Jigsaw Puzzle cutting method}

After the implementation of the Jigsaw Puzzle cutting method, the data to analyze the improvement of the section from the implementation of the new cutting method in ELICO -Universal Leather Products Industry, the record result were as shown in Table 9,10,11 below.

Table 9. Trial one and trial two leather-cutting waste recorded after the implementation of jigsaw puzzle cutting method 


\begin{tabular}{|c|c|c|c|c|c|c|c|c|c|}
\hline \multicolumn{10}{|c|}{ Leather cutting waste recorded data } \\
\hline \multicolumn{10}{|l|}{ Trial 1} \\
\hline Color & \multicolumn{9}{|l|}{ Black } \\
\hline Thickness & \multicolumn{9}{|l|}{1.5} \\
\hline Type & \multicolumn{9}{|c|}{ Oil pull-up leather } \\
\hline Grade & \multicolumn{9}{|l|}{ B } \\
\hline Cut 1 & Cut 2 & Cut 3 & Cut 4 & Cut 5 & Cut 6 & Cut 7 & Cut 8 & Cut 9 & Cut 10 \\
\hline \multicolumn{10}{|c|}{ Total cutting area $\left(\mathrm{m}^{2}\right)$} \\
\hline 126.48 & 131.86 & 120.02 & 110.33 & 121.10 & 102.26 & 121.64 & 151.78 & 153.39 & 158.77 \\
\hline \multicolumn{10}{|c|}{ Generated leather waste scrap $\left(\mathrm{m}^{2}\right)$} \\
\hline 85.96 & 14.04 & 73.63 & 11.99 & 90.41 & 80.82 & 115.07 & 76.03 & 83.90 & 152.40 \\
\hline \multicolumn{10}{|c|}{ Cutting efficiency $(\%)$} \\
\hline 21.36 & 3.34 & 19.28 & 3.41 & 23.46 & 24.84 & 29.73 & 15.74 & 17.91 & 30.16 \\
\hline \multicolumn{10}{|l|}{ Trial 2} \\
\hline Color & Black & & & & & & & & \\
\hline Thickness & 1.7 & & & & & & & & \\
\hline Type & Oil pull-ı & leather & & & & & & & \\
\hline Grade & B & & & & & & & & \\
\hline Cut 1 & Cut 2 & Cut 3 & Cut 4 & Cut 5 & Cut 6 & Cut 7 & Cut 8 & Cut 9 & Cut 10 \\
\hline \multicolumn{10}{|c|}{ Total cutting area $\left(\mathrm{m}^{2}\right)$} \\
\hline 137.24 & 130.79 & 110.33 & 142.63 & 153.39 & 123.79 & 143.16 & 151.78 & 153.39 & 158.77 \\
\hline \multicolumn{10}{|c|}{ Generated leather waste scrap $\left(\mathrm{m}^{2}\right)$} \\
\hline 27.02 & 4.41 & 12.38 & 3.77 & 28.42 & 25.40 & 36.17 & 24.22 & 15.61 & 37.14 \\
\hline \multicolumn{10}{|c|}{ Cutting efficiency $(\%)$} \\
\hline 19.68 & 3.37 & 11.21 & 2.64 & 18.52 & 20.52 & 25.26 & 15.95 & 10.17 & 23.38 \\
\hline
\end{tabular}

Note: *Red=amount of cutting operation done, Blue=total cutting area covered, Green= generated leather waste scrap from each cutting operation, Rose=cutting efficiency for each cutting operation: Measured in $\mathrm{m}^{2}$,

Table 10.Trial three and trial four leather-cutting wastes recorded after the implementation of the jigsaw puzzle cutting method 


\begin{tabular}{|c|c|c|c|c|c|c|c|c|c|}
\hline \multicolumn{10}{|l|}{ Trial 3} \\
\hline Color & \multicolumn{9}{|l|}{ Black } \\
\hline Thickness & \multicolumn{9}{|l|}{1.7} \\
\hline Type & \multicolumn{9}{|c|}{ Oil pull-up leather } \\
\hline Grade & \multicolumn{9}{|l|}{ A } \\
\hline Cut 1 & Cut 2 & Cut 3 & Cut 4 & Cut 5 & Cut 6 & Cut 7 & Cut 8 & Cut 9 & Cut 10 \\
\hline \multicolumn{10}{|c|}{ Total cutting area $\left(\mathrm{m}^{2}\right)$} \\
\hline 141.55 & 141.55 & 120.02 & 126.48 & 153.39 & 141.01 & 141.01 & 141.01 & 153.39 & 169.54 \\
\hline \multicolumn{10}{|c|}{ Generated leather waste scrap $\left(\mathrm{m}^{2}\right)$} \\
\hline 16.25 & 11.84 & 12.38 & 14.53 & 28.42 & 14.64 & 23.25 & 26.91 & 23.14 & 37.14 \\
\hline \multicolumn{10}{|c|}{ Cutting efficiency $(\%)$} \\
\hline 11.48 & 8.36 & 11.33 & 12.55 & 18.52 & 11.23 & 17.85 & 19.08 & 15.08 & 21.9 \\
\hline \multicolumn{10}{|l|}{ Trial 4} \\
\hline Color & \multicolumn{9}{|l|}{ Black } \\
\hline Thickness & \multicolumn{9}{|l|}{1.7} \\
\hline Type & \multicolumn{9}{|c|}{ Oil pull-up leather } \\
\hline Grade & \multicolumn{9}{|l|}{ B } \\
\hline Cut 1 & Cut 2 & Cut 3 & Cut 4 & Cut 5 & Cut 6 & Cut 7 & Cut 8 & Cut 9 & Cut 10 \\
\hline \multicolumn{10}{|c|}{ Total cutting area $\left(\mathrm{m}^{2}\right)$} \\
\hline 158.77 & 152.31 & 122.17 & 126.48 & 153.39 & 147.47 & 132.40 & 151.78 & 153.39 & 158.77 \\
\hline \multicolumn{10}{|c|}{ Generated leather waste scrap $\left(\mathrm{m}^{2}\right)$} \\
\hline 10.76 & 5.38 & 11.84 & 3.23 & 17.65 & 14.64 & 25.40 & 13.46 & 15.61 & 26.37 \\
\hline \multicolumn{10}{|c|}{ Cutting efficiency $(\%)$} \\
\hline 6.77 & 3.53 & 9.69 & 2.55 & 11.5 & 9.92 & 19.18 & 8.86 & 10.17 & 16.61 \\
\hline
\end{tabular}

Note: *Red=amount of cutting operation done, Blue=total cutting area covered, Green= generated leather waste scrap from each cutting operation, Rose=cutting efficiency for each cutting operation: Measured in $\mathrm{m}^{2}$

Table 11.Trial five and trial six leather cutting waste recorded after implementation of jigsaw puzzle cutting method 


\begin{tabular}{|c|c|c|c|c|c|c|c|c|c|}
\hline \multicolumn{10}{|l|}{ Trial 5} \\
\hline Color & \multicolumn{9}{|l|}{ Black } \\
\hline Thickness & \multicolumn{9}{|l|}{1.5} \\
\hline Type & \multicolumn{9}{|c|}{ Oil pull-up leather } \\
\hline Grade & \multicolumn{9}{|l|}{ B } \\
\hline Cut 1 & Cut 2 & Cut 3 & Cut 4 & Cut 5 & Cut 6 & Cut 7 & Cut 8 & Cut 9 & Cut 10 \\
\hline \multicolumn{10}{|c|}{ Total cutting area $\left(\mathrm{m}^{2}\right)$} \\
\hline 169.54 & 153.39 & 150.16 & 128.63 & 152.31 & 151.78 & 149.62 & 152.74 & 160.93 & 160.93 \\
\hline \multicolumn{10}{|c|}{ Generated leather waste scrap $\left(\mathrm{m}^{2}\right)$} \\
\hline 5.38 & 2.15 & 5.38 & 3.77 & 17.65 & 14.64 & 14.64 & 10.76 & 15.07 & 20.99 \\
\hline \multicolumn{10}{|c|}{ Cutting efficiency $(\%)$} \\
\hline 3.17 & 1.4 & 3.58 & 2.92 & 11.59 & 9.64 & 9.78 & 7.04 & 9.36 & 13.04 \\
\hline \multicolumn{10}{|l|}{ Trial 6} \\
\hline Color & \multicolumn{9}{|l|}{ Black } \\
\hline Thickness & \multicolumn{9}{|l|}{1.7} \\
\hline Type & \multicolumn{9}{|c|}{ Oil pull-up leather } \\
\hline Grade & \multicolumn{9}{|l|}{ B } \\
\hline Cut 1 & Cut 2 & Cut 3 & Cut 4 & Cut 5 & Cut 6 & Cut 7 & Cut 8 & Cut 9 & Cut 10 \\
\hline \multicolumn{10}{|c|}{ Total cutting area $\left(\mathrm{m}^{2}\right)$} \\
\hline 169.54 & 153.39 & 160.93 & 150.16 & 152.31 & 151.78 & 149.62 & 152.74 & 160.93 & 160.93 \\
\hline \multicolumn{10}{|c|}{ Generated leather waste scrap $\left(\mathrm{m}^{2}\right)$} \\
\hline 5.49 & 4.41 & 2.15 & 2.15 & 5.38 & 10.76 & 5.38 & 2.15 & 5.38 & 5.38 \\
\hline \multicolumn{10}{|c|}{ Cutting efficiency $(\%)$} \\
\hline 3.23 & 2.87 & 1.33 & 1.43 & 3.53 & 7.09 & 3.59 & 1.4 & 3.34 & 3.34 \\
\hline
\end{tabular}

Note: *Red=amount of cutting operation done, Blue=total cutting area covered, Green= generated leather waste scrap from each cutting operation, Rose=cutting efficiency for each cutting operation: Measured in $\mathrm{m}^{2}$ '

Table 12. Total leather-cutting Consumption, Leather Shortage and saving (Average Value) after implementation jigsaw puzzle cutting method

\begin{tabular}{|c|c|c|c|c|c|c|c|}
\hline \multirow{2}{*}{\multicolumn{8}{|c|}{$\begin{array}{l}\text { Monthly Leather Cutting Total Consumption and Leat } \\
\text { After implementation jigsaw puzzle cutting method }\end{array}$}} \\
\hline & & & & & & & \\
\hline $\begin{array}{l}\text { No } \\
\text { week }\end{array}$ & $\begin{array}{l}\text { Leather Cutting } \\
\text { Norms for one pair } \\
\left(\mathrm{m}^{2}\right)\end{array}$ & $\begin{array}{l}\text { Total Leather } \\
\text { Cuttability per } \\
\text { day }\end{array}$ & $\begin{array}{l}\text { Total } \\
\text { no. of } \\
\text { pairs }\end{array}$ & $\begin{array}{l}\text { Leather Cutting } \\
\text { Consumption } \\
\left(\mathrm{m}^{2)}\right.\end{array}$ & $\begin{array}{l}\text { Leather } \\
\text { Shortage } \\
\text { (Extra Norms }\end{array}$ & $\begin{array}{l}\text { Leather } \\
\text { Saving } \\
\text { Norms in } \\
\left(\mathrm{m}^{2}\right)\end{array}$ & $\begin{array}{l}\text { International Leather Cutting } \\
\text { Loss Norms }\left(\mathrm{m}^{2}\right) \text { Based On } \\
\text { Grade }\end{array}$ \\
\hline 1 & 34.98 & $6 * 720$ & 4320 & 151130.25 & $1.28 \%$ & 0 & A, B, C grade $1.20 \%$ \\
\hline 2 & 36.17 & $6 * 569$ & 3414 & 123477.29 & 0 & $1.75 \%$ & C, D grade $1.5-1.70 \%$ \\
\hline 3 & 27.56 & $6 * 751$ & 4506 & 124169.64 & 0 & $2.75 \%$ & A, B, C grade $1.20 \%$ \\
\hline 4 & 30.89 & $6 * 553$ & 3318 & 102504.41 & 0 & $2.99 \%$ & A, B, C grade $1.20 \%$ \\
\hline 5 & 33.91 & $6 * 665$ & 3990 & 135290.64 & 0 & $3.15 \%$ & \\
\hline
\end{tabular}

Figure 5 shows that the study determined that leather-cutting norms for one pair shoe are different from one design to another design, leather-cutting consumption of the company are different from one to other week and after implementation of jigsaw cutting method Leather Shortage (Extra Norms) totally eliminated and Leather Saving Norms was increased. 
Figure 4 shows that the study determined that the total cutting area after the implementation of jigsaw cutting method in trial one $1297.63 \mathrm{~m}^{2}$, trial two $1405.27 \mathrm{~m}^{2}$, trial three $1428.96 \mathrm{~m}^{2}$, trial four $1456.94 \mathrm{~m}^{2}$, trail five $1530.03 \mathrm{~m}^{2}$ and trial six was $1562.33 \mathrm{~m}^{2}$ this shown as the total cutting area of a leather increase, total generated leather waste scraps in trial one $784.25 \mathrm{~m}^{2}$, trial two $214.53 \mathrm{~m}^{2}$, trial three $208.50 \mathrm{~m}^{2}$, trial four $144.35 \mathrm{~m}^{2}$, trial five $110.44 \mathrm{~m}^{2}$, trial six was $48.65 \mathrm{~m}^{2}$ of leather scraps this shown us the leather scrap waste was decrease after implementation jigsaw cutting method and the cutting efficiency was improved.

The first two month leather cutting efficiency was evaluated and the final result was better than the previous production. Leather cutting is basic key word of footwear production; nowadays there are many technologies to process the footwear like Auto CAD, Automation machines. Laser leather cutting, advanced computerized stitching machines, etc. So we should adopt the new technologies to build our processing plants, we could communicate with European and North American countries for modern technologies. Skilled human resources are other important parameters for manufacturing of footwear. Educated, hardworking, creative and innovative minded young generation is a good source of skilled human resources (14) they should be trained first about the footwear and cutting technologies. This Economical research work gives more information about leather-cutting issues and prevention of leather cutting quality problems and reduces the leather consumption stages. The research result is more benefit for footwear industry-cutting sections. The Quality is the main factor for any business, branding is the most important factor aspects to get the global market reputation in footwear sectors. Nike, Rebook, Clarks, hotter, kicker France's, aster, Marker and Spencer, some other is world famous reputation in footwear. So we should take proper steps to develop a world famous brand by ensuring attractive design, price and quality. Middle sectors quality implementation must be and the same time foreign investors are only investing when they found political stability and company quality, price, delivery moments is the above factors is satisfied developing country middle sector easily will pick up. This research gives more attention to the footwear industry leather cutting section such as Leather processing quality assortment, leather cutting grading techniques important, cutting manual nesting, cutting knowledge importance's, lake-cutting issues, cutting board and machine-maintained activity. Edge fraying cutting issues, time study importance, stroke report systems, Die maintenance techniques, cutting die size intimation, standard operating process systems, material-saving record, Leather assortment importance is clearly identified the above such technical methods. Abnormal cutting issues avoided by this research techniques are SOP systems, Die check list, Model form Die data, cutting allocation sheet, QC verification systems, Hourly quality reports, Motivation factors, it is useful for improve the cutting efficiency to developed country footwear sectors, After one month the same company leather cutting section total productivity of cutting, Quality of cut components status, leather cutting consumption gradually reduced by this system implementation . Footwear industry leather cutting common and critical technical issues also clearly analysed in this research articles and introduced action plan techniques to control the above such problems. Leather norms and cuttabilty coefficient, leather cost , the importance of cutting process intimation also useful for gathering more about footwear production to cutting operators. This industrial research work mainly refers to leather assortment, grading, Nesting issues, Die interlocking techniques and wastage reduction methods.

\section{Conclusion}

This research analysed and identified the leather components cutting current issues and refers to the quality implementation techniques in each cutting process. Footwear cutting sections nowadays meet lot of problems like unskilled human resources, leather cutting defect issues, lower cutting efficiency, loose leather components cutting problems, uneven grain pair matching, color matching (particularly in suede, nuebuck leather cutting), cutting record improper maintains , poor supervision, cutting die poor maintains etc. This research result is specially focused on the above area and each process it referred the modern techniques. Here lot cattle population is available and raw material is cost wise much cheaper than Asian countries (15). In this way they like African countries, so middle sector having a lot of quality knowledge, production efficiency, on time shipment delivery, customer relationship etc. Quality abnormal is major problems in all footwear industry in the world; this poor quality administration is affecting the total industry development activities. Now days Asian countries like China, India, Bangladesh, Vietnam, Taiwan is fast developing moments in footwear industry development .In African countries having several human resources and cattle population than in other countries, it will focus for footwear industry developments after 10 years African countries is to be biggest footwear export ranks for the world. Based on the above sources and current Ethiopian footwear industry leather cutting productivity, thus the research was conducted in ELICO -Universal Leather Products and the final output is much more economic benefit to the middle scale footwear sectors. The company prepares well organized training for the operators to improve operator cutting skill, machine handling and material handling and to impart basic knowledge about the cutting operation and how to achieve quality of cutting operation.

\section{Declarations}

\section{AVAILABILITY DATA AND MATERIALS}

The primary data used to support the findings of this study are included within the article.

\section{ETHICAL APPROVAL}

Not applicable

\section{CONFLICTS OF INTEREST}

They have no conflicts of interest

\section{FUNDING}

Not applicable 


\section{CONSENT TO PARTICIPATE}

The authors consent to participate in this work.

\section{CONSENT TO PUBLISH}

The authors consent to the publication of this work.

\section{COMPETING INTERESTS}

The author declare no competing interests

\section{References}

1. GERGIEV, Lidia, KALOYAN Krastev, Nikola Angelo. Identification of leather surface defects. International conference on computer system and technologies, online publication, 2003. <https://www.dl.acm.org/doi/10.1145/973620.973670.

2. TEKLAY, A, GETACHEW Terefe, GEBEYEHU'S G, YAYNESHET Tesfay. Quantification of Solid Waste Leather Generation Rate from the Ethiopian Leather Sector - A Contributing Perspective to Waste Management Approach. 2018 7(2)

3. MIRUNALINI V. waste management in leather industry - environmental and health effects and suggestions to use in construction purposes. International Journal of Civil Engineering and Technology, 2017, 8(4).

4. ABU Sayid Mia, Nur -E- Alam, WAHID Murad's, FARID Ahmad. Waste Management \& Quality Assessment of Footwear Manufacturing Industry in Bangladesh: An Innovative Approach. International Journal of Engineering and Management Research. 2017, 7(4)

5. SARKAR, KT. Defects of hide and skins in theory and practice of leather manufacture, 2005, 50-52.

6. HABIB A.B, NOOR L.A. Musa Effects of some skin Defects and physical properties of the leather. Journal applied and industrial sciences, 2015.

7. SATRA, One language for leather assessment. Insight November 2007.

8. IRAIVAN Elamvazhuthi, SUSANA Kamaruddin, MOHD Shahrul azmi. Automation of nesting and cutting process of leather furniture; A Case study. International journal of mechanical engineering IJMME-IJENS, 2009.

9. SMITH G, CLAUSTRE T. A case study on concept Design and CAD modelling in the footwear industry. International Design conference, 2006 online publication<https://www.designsociety.org/publication/19024/A+CASE+STUDY+ON+CONCEPT+DESIGN+AND+CAD+MODELLING+IN+THE+FOOTWEAR+

10. PARAG Kohli, SHALVI Garg. Leather quality estimation using automated machine vision systems. IOSR journal, 2013 6(3).

11. ETHIOPIAN DEVELOPMENT RESEARCH INSTITUTE EDRI-REPORT 2013 publication in online. <https://library.wmo.int/index.php? $|v|=$ author_see\&id=10688\#.X2h2_GhKiUk.

12. TETSUSHI Sonobe, JOHN E. Akoten, KEIJIRO Otsuka. The development of leather footwear industry in Ethiopia; How different is it from the Asian experience. Global development network conference Beijing china, 2007.

13. Analysis of the Luxury goods and apparel and Footwear industries, 2013 publication in online. <https://citeseerx.ist.psu.edu/viewdoc/download? doi=10.1.1.579.7389\&rep=rep $1 \&$ type $=$ pdf.

14. SIMONE Cipriani. Study of the quality control and managements on the African leather sector, 2002 African meeting publication.

15. BIRKENESH Gonfa. Competitiveness of Ethiopian shoe industry; Research to export market, Addis Ababa University, 2012.

16. VASILIKI Tsaknaki, YIVA Fernaeus, MISHA Schaub. Leather as a Material for grafting interactive and physical artefacts, DIS-2014 Canada publication.

17. Future trends in the world leather and leather products industry and trade, Vienna 2010 Publication.

18. GLENN A. BOWEN. From Qualitative Dissertation to quality articles -seven lessons, 2010, western Carolina University USA, volume 15

\section{Figures}




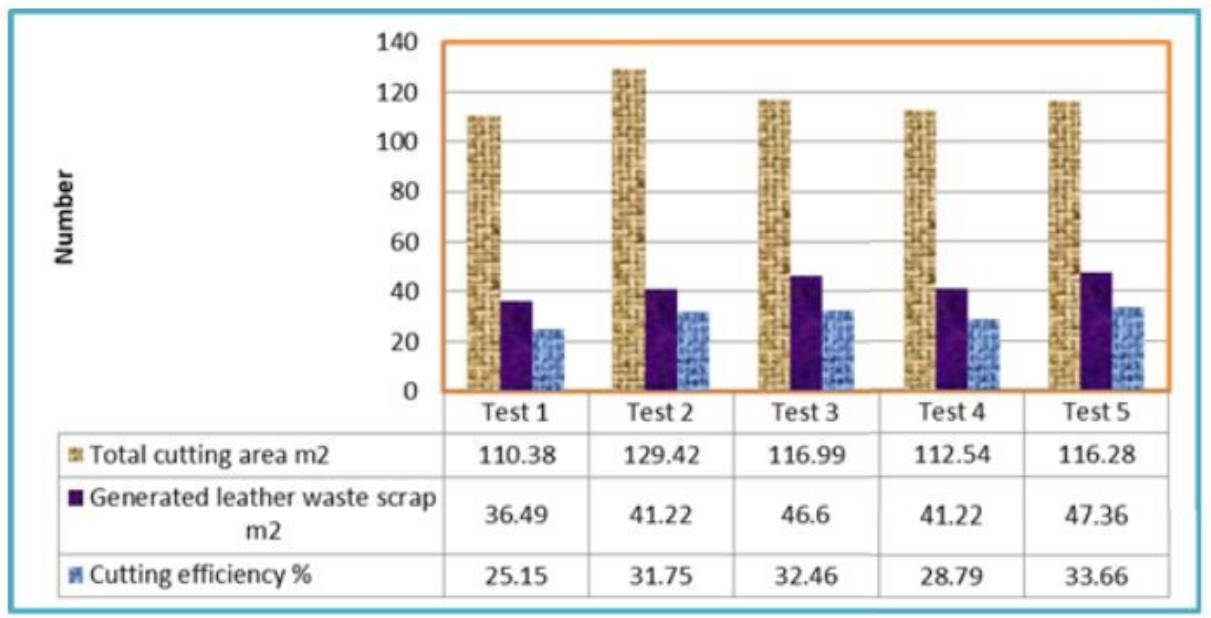

Figure 1

Summary of recorded data leather cutting waste before implementation jigsaw cutting method

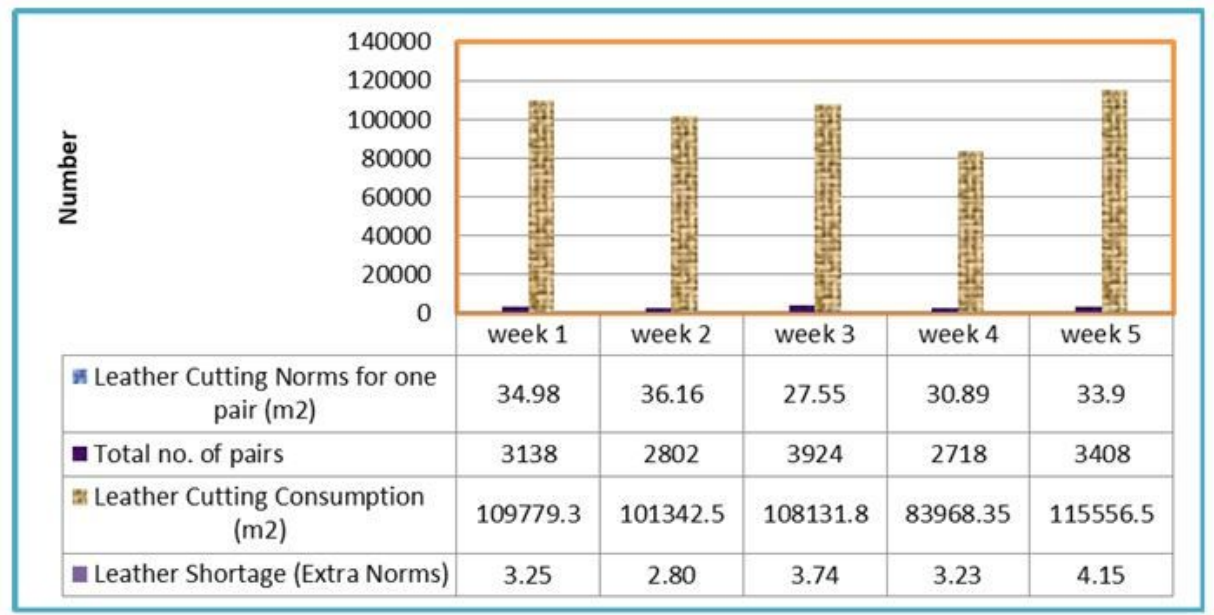

Figure 2

Summary of Leather Cutting Total Consumption and Leather Shortage, saving details (Average Value) before implementation jigsaw cutting method

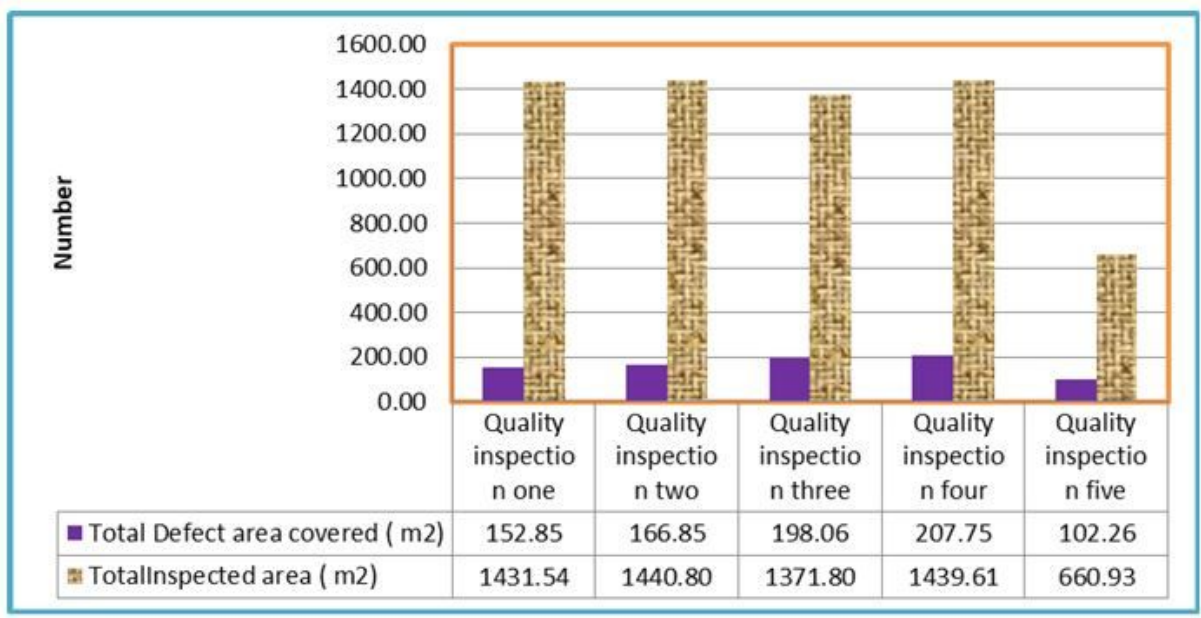

\section{Figure 3}

Summery data of quality inspection in cutting section 


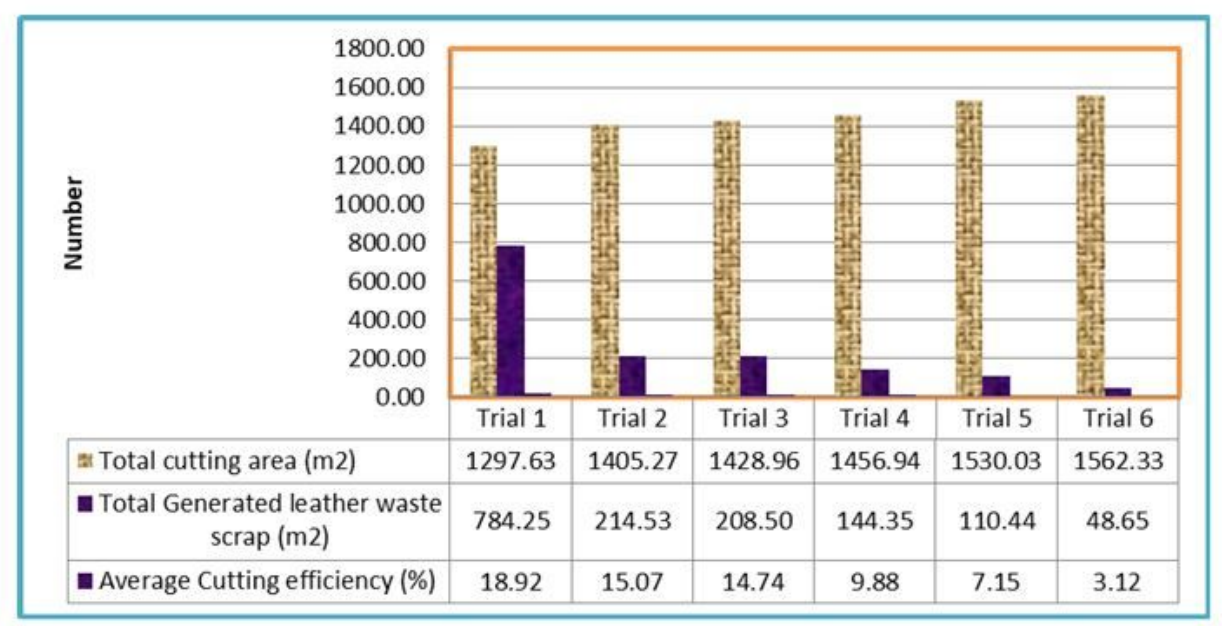

Figure 4

Summary of recorded data leather cutting waste after implementation jigsaw cutting method

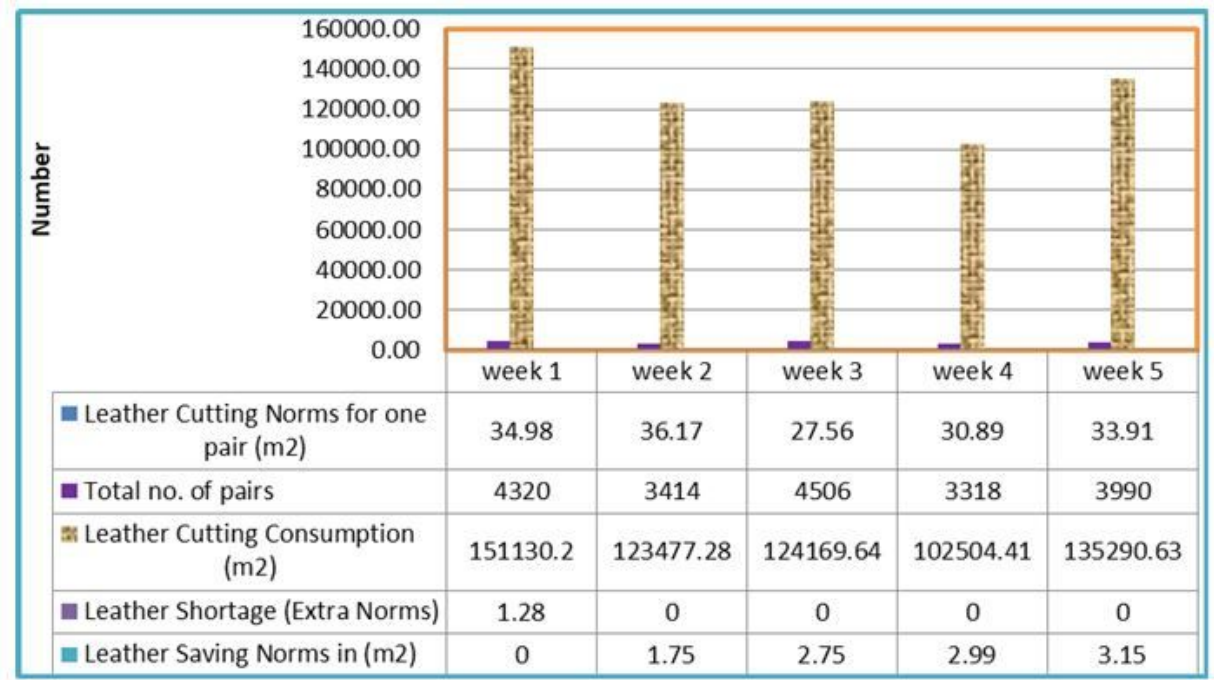

Figure 5

Summary of Leather Cutting Total Consumption and Leather Shortage, saving details (Average Value) after implementation jigsaw cutting method 